\title{
Optimization of fabric drape measurement based on 3D model
}

DOI: 10.35530/IT.070.04.1552

AZMAT HUSSAIN

WANG XIN

TAYYAB NAVEED

IQBAL WAQAR

DANISH IQBAL

YUEQI ZHONG

ZHICAI YU

\section{REZUMAT - ABSTRACT}

\section{Optimizarea determinării drapajului materialelor textile pe baza modelului 3D}

Drapajul este o caracteristică importantă a materialului textil, corelându-se în principal cu rigiditatea acestuia. Această caracteristică este evaluată obiectiv cu un indicator, respectiv coeficientul de drapaj (DC). Coeficientul de drapaj se calculează pe baza suprafaței bidimensionale de proiecție a probei cu drapaj tridimensional (3D). În acest studiu, se evaluează modelul de drapaj tridimensional (3D) și se prezintă o nouă bază a suprafeței cu funcție de secționare. Suprafața propusă a fost calculată cu ajutorul unui plan orizontal, care a secționat modelul de drapaj 3D (curba de secțiune), chiar deasupra celui mai înalt punct al curbei reale limită. Coeficientul de drapaj modificat (MDC) a fost comparat cu cel inițial DC, în ceea ce privește rezistența la încovoiere. Rezultatele au demonstrat că rezistența la încovoiere înregistrează valori optime cu MDC, în comparație cu DC. Rezultă astfel că, MDC este mai eficient în evaluarea drapajului materialelor textile.

Cuvinte-cheie: rezistența la încovoiere, proiecție drapaj, coeficient de drapaj modificat, funcție de secționare, drapaj tridimensional

\section{Optimization of fabric drape measurement based on 3D model}

Drapability is an important characteristic of fabric appearance, mainly correlates to its stiffness. It is evaluated objectively with a dominant indicator, drape coefficient (DC). Drape coefficient is based on the two-dimensional projection-area of three-dimensional (3D) draped sample. In this study, three dimensional (3D) drape-model is evaluated and a new basis of the area is revealed with slice function. The proposed area was calculated using a horizontal plane that cut the $3 D$ drape-model (slice curve) just above the highest point of actual boundary-curve. Modified drape coefficient (MDC) was compared with DC against bending stiffness. The results demonstrate that the bending stiffness has better conformance with MDC than that of DC. This implies that MDC is more effective in evaluating fabric drapability.

Keywords: bending stiffness, drape projection, modified drape coefficient, slice function, three dimensional drape

\section{INTRODUCTION}

Fabric drape is a complex and three dimensional (3D) phenomenon of fabric appearance and appeal. It is influenced dominantly with bending stiffness [1-2] among many other properties of fabric. Fabric drape is evaluated objectively with 'drape coefficient' (DC) [3], however, equivalent DC is possible for fabrics having different bending rigidities. Therefore, DC is unable to characterize the fabric 3D drape [4].

Traditionally, fabric and garment designers assess its drape subjectively in an informal manner. Apparel fashion-designers do extensive efforts to visualize the actual appearance of fabric drape. Initially, they create a pattern on certain fabrics and make a garment to fit on a mannequin, with continuous corrections [5]. In 1950 Chu et al. quantified fabric drapability into an objective value DC [6]. Cusick reinvestigated the method with the same measuring principle i.e. two dimensional (2D) projection from 3D fabric drape in the more efficient way [7].

Further investigations have been focused on improving the efficacy and digitization of Cusick method by the use of techniques like photovoltaic cells [8], image processing [9-13], fractal dimensions [14-15], Fourier Expansion [16] and computer simulation [17], offered efficacy, measuring reliability and different drape indicators. These indicators are based on drape area and perimeter, radius, node, profile and 3D simulation. Among them, DC is the most widely used, which is the ratio of projected area of fabric sample hung under the gravitational field over a circular support disk to the area if it is completely rigid. Albeit, these techniques are more efficient in time-saving and reliability than that of the conventional paper tracing method (i.e. Cusick method), the measurements are based on a $2 \mathrm{D}$ projection of $3 \mathrm{D}$ fabric deformation. Therefore, DC is unable to fully characterize 3D drape-shape [14].

Emerging technologies have been used to determine the 3D drape of fabrics [18]. For instance, 3D scanned images contain vast information and allow further analysis of fabric drape. Scientists [19] explored the 3D scanned images for DC however, the improvement in the measuring accuracy for soft fabrics was only $5 \%$. It has been argued that fabric 
shear and bending were the potential fabric properties which cause shape variations within drape and folds [8,13], and final sample drape geometry is attained by the support of adjacent sides. However, due to boundary heights fluctuations [20] support to the adjacent sides vary below the highest point of 3D drape-model boundary. This doubts the consideration of projected area for the actual drape evaluation. Thus, there is a need to reinvestigate the complex drape phenomenon to develop new 3D indicator by considering a suitable area for drape evaluation.

In this study, a modification in the measurement of $\mathrm{DC}$ is proposed by the analysis of $3 \mathrm{D}$ drape model. Multiple depth cameras were used to reconstruct the 3D drape-model. Evaluation of these drape models revealed a new area instead of projection area, based on which the modification in the previous drape indicator (DC) is proposed. The performance of modified drape-coefficient (MDC) is also compared with the DC against bending stiffness.

\section{MATERIALS AND METHODS}

Thirteen different commercial fabrics (woven) were collected with a wide range of thickness, GSM, yarn count and fabric densities. The specifications of the fabric samples are listed in table 1. All the samples were evaluated objectively in the standard ambient conditions i.e. $20 \pm 2^{\circ} \mathrm{C}$ temperature, and $65 \pm 2$ R.H \%. Self-made drape-meter was used to reconstruct the 3D fabric drape model (figure 1). The drape meter consisted of a supporting disk and a pillar. The disk has $12 \mathrm{~cm}$ diameter, similar to the commercially available XDP-1. The fabric samples (240 mm diameter) were hanged freely over the support disk under the gravitational force.

Table 1

\begin{tabular}{|c|c|c|c|c|}
\hline \multicolumn{5}{|c|}{ FABRIC CHARACTERISTICS } \\
\hline $\begin{array}{c}\text { Sample } \\
\text { ID }\end{array}$ & $\begin{array}{c}\text { Density } \\
\text { (numbers } \\
\text { of warp \& } \\
\text { weft /inch) }\end{array}$ & $\begin{array}{c}\text { Thickness } \\
\text { (mm) }\end{array}$ & $\begin{array}{c}\text { Mass per } \\
\text { unit area } \\
\left(\mathrm{g} / \mathrm{m}^{2}\right)\end{array}$ & $\begin{array}{c}\text { Yarn count } \\
\text { warp/weft } \\
\text { (Tex) }\end{array}$ \\
\hline S1 & $84 * 64$ & 0.63 & 300 & $24 * 24$ \\
\hline S2 & $80 * 80$ & 0.24 & 105 & $8.3^{*} 8.3$ \\
\hline S3 & $80 * 58$ & 0.33 & 240 & $22 * 20$ \\
\hline S4 & $70 * 82$ & 0.31 & 267 & $25^{\star} 20$ \\
\hline S5 & $60 * 60$ & 0.66 & 435 & $50 * 38$ \\
\hline S6 & $108^{*} 90$ & 0.31 & 277 & $22 * 19$ \\
\hline S7 & $43 * 38$ & 0.46 & 300 & $50 * 50$ \\
\hline S8 & $68 * 54$ & 0.37 & 234 & $28 * 28$ \\
\hline S9 & $44 * 38$ & 0.45 & 299 & $59 * 59$ \\
\hline S10 & $51 * 47$ & 0.44 & 304 & $54 * 54$ \\
\hline $\mathrm{S} 11$ & $52 * 58$ & 0.29 & 208 & $28 * 28$ \\
\hline S12 & $52 * 53$ & 0.28 & 190 & $34 * 28$ \\
\hline S13 & $54^{\star} 50$ & 0.43 & 258 & $28^{*} 28$ \\
\hline
\end{tabular}

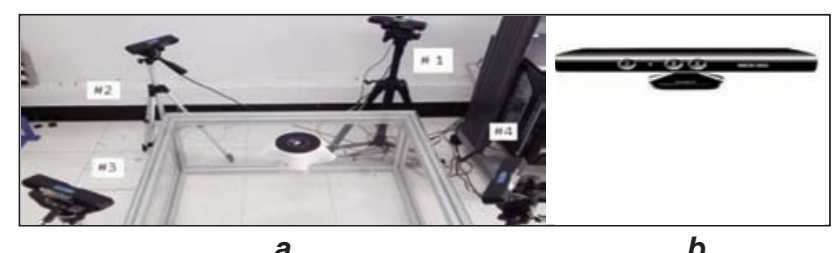

a

b

Fig. 1. Arrangement of multiple depth-cameras for 3D drape scan: $a$ - arrangement of four multiple depth cameras and drape-meter; $b$ - depth camera

\section{Slice area}

\section{Reconstruction of 3D Drape-Model}

To reconstruct the 3D drape models, fabric samples were placed on drape-meter (figure 1) and scanned at different locations by multiple depth cameras using a method developed in our earlier research [21-22]. We made a modification on this method with four depth cameras instead of six. After extracting the points cloud from multiple depth cameras, drape images were processed in Geomagic software for denoising. The average dimensional error of the final fabric model was around 2-3 $\mathrm{mm}$.

\section{Three-dimensional drape evaluation}

As an effort to benefit from the 3D drape information, the evaluation of 3D drape models using slice function is elaborated in figure 2 . The details of slice function are described in our earlier research [21]. This method used two dimensional planes parallel to horizontal axis over the 3D drape model at various vertical positions. In this research, we considered ten vertical positions on the 3D drape model as shown in dotted red lines (figure 2,b,c). Three dimensional drape model in figure 2, a displays its cross-sectional view with slice curves in figure 2,b. Figure 2, c shows the front view where top slice stays $5 \mathrm{~mm}$ below the highest vertical point and bottom slice at the top point of 3D boundary curve of drape model. The projection boundary of the 3D draped model is shown in solid line in figure 2, $b, c$.

For the performance assessment of modified drape indicator, bending-stiffness was calculated using Stiffness Tester objectively [23]. A rectangular fabricstrip was placed on a horizontal support of the stiffness tester and slid in the direction of its length. The fabric increasing part hanged under its own weight to a specific angle $\left(41.5^{\circ}\right)$. The overhang length $(L)$ both in weft and warp direction was noted as a mean value of five samples each. Bending length $(c)$ is then given by Eq. 1

$$
c \approx \frac{L}{2}
$$

\section{RESULTS AND DISCUSSIONS}

\section{Slice area}

Three-dimensional drape models were explicitly analyzed with slice function to identify the optimum area for the modification in drape evaluation. The shapes of slice curves obtained at various vertical heights on 


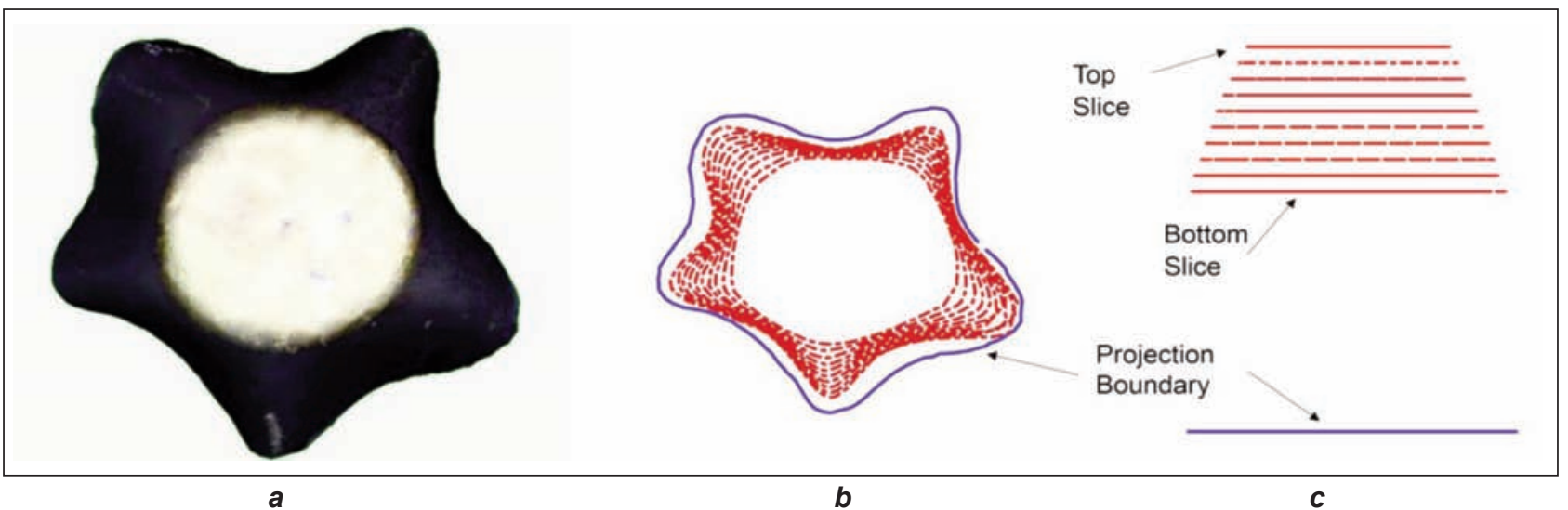

Fig. 2. Slice curves and projection boundary of 3D drape model: $a-3 D$ drape model; $b-$ cross-sectional view of slices; $c$ - front view of slices

the draped model are shown in figure 3. The figure shows the gradual change in slice shapes from the first (top) slice to last (bottom) slice. As the slice position descended (top to bottom), the area was increased; at the same time, node positions and their numbers remained the same. These fundamental characteristics of 3D fabric drape were determined at the time of initial node generation (i.e., top slices). Though, refinement in node shape was achieved as the position of slice curves descended over the 3D drape model. Maximum refinement in the drape shape was obtained at the $10^{\text {th }}$ slice position (bottom slice). Thus, the bottom slice was chosen for further objective evaluation of fabric drape. However, below the $10^{\text {th }}$ (bottom) slice position, due to variations in the 3D drape-model boundary heights, fabric edges lose support from the adjacent sides and ultimately shape relaxation at the projected boundary-curve was noted. This effect is shown between $10^{\text {th }}$ (bottom) slice and projected boundary curve of the draped sample in figure 3 . The impact is noted more intensified for stiffer fabrics (figure 4).

(S)

Fig. 3. Change in slice shapes at various descent positions on 3D drape model

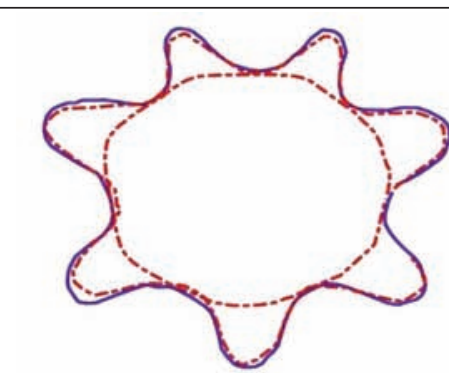

Soft

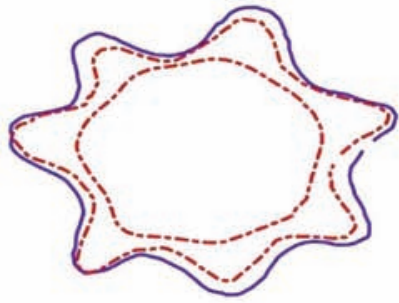

Moderate rigid

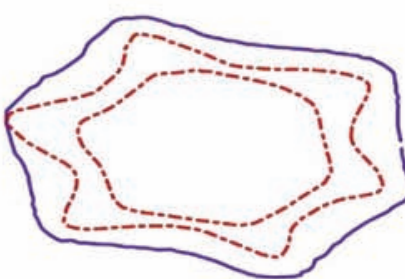

Rigid

Fig. 4. Comparison of top slice, bottom slice and projection curves for the soft, moderate rigid and rigid fabrics; dotted-line for top and bottom slice curves and solid line for projection curve 


\begin{tabular}{|c|c|c|c|c|c|c|c|c|c|}
\hline \multicolumn{10}{|c|}{ ANALYSIS OF DRAPE AREA } \\
\hline \multirow{2}{*}{$\begin{array}{c}\text { Sample } \\
\text { ID }\end{array}$} & \multirow{2}{*}{$\begin{array}{l}\text { Class } \\
\text { name }\end{array}$} & \multirow{2}{*}{$\begin{array}{l}\text { Class } \\
\text { label }\end{array}$} & \multicolumn{2}{|c|}{ Range $\left(\mathrm{cm}^{2}\right)$} & \multicolumn{2}{|c|}{ Mean $\left(\mathrm{cm}^{2}\right)$} & \multirow{2}{*}{$\begin{array}{l}\text { Standard } \\
\text { deviation } \\
\text { (MDC) }\end{array}$} & \multirow{2}{*}{ MDC* } & \multirow{2}{*}{ DC } \\
\hline & & & BSA* $^{*}$ & $\mathrm{PA}^{*}$ & BSA & PA & & & \\
\hline S1 & \multirow{2}{*}{ Soft } & 1.0 & \multirow{2}{*}{5.2} & \multirow{2}{*}{25.2} & \multirow{2}{*}{71.2} & \multirow{2}{*}{89.1} & 1.27 & 20.2 & 22.6 \\
\hline $\mathrm{S} 2$ & & 1.0 & & & & & 1.23 & 21.7 & 30.0 \\
\hline S3 & \multirow{7}{*}{$\begin{array}{l}\text { Moderate } \\
\text { rigid }\end{array}$} & 2.0 & \multirow{7}{*}{14.5} & \multirow{7}{*}{70.1} & \multirow{7}{*}{103.2} & \multirow{7}{*}{160.6} & 2.84 & 31.5 & 49.1 \\
\hline S4 & & 2.0 & & & & & 2.49 & 28.0 & 46.4 \\
\hline S5 & & 2.0 & & & & & 0.25 & 32.0 & 41.9 \\
\hline S6 & & 2.0 & & & & & 0.79 & 31.5 & 40.8 \\
\hline S7 & & 2.0 & & & & & 2.53 & 28.9 & 39.8 \\
\hline S8 & & 2.0 & & & & & 1.49 & 32.3 & 60.4 \\
\hline S9 & & 2.0 & & & & & 2.41 & 29.4 & 52.7 \\
\hline $\mathrm{S} 10$ & \multirow{4}{*}{ Rigid } & 3.0 & \multirow{4}{*}{52.8} & \multirow{4}{*}{42.7} & \multirow{4}{*}{142.1} & \multirow{4}{*}{213.7} & 1.59 & 35.3 & 68.8 \\
\hline S11 & & 3.0 & & & & & 2.94 & 43.1 & 59.8 \\
\hline S12 & & 3.0 & & & & & 1.49 & 38.2 & 56.2 \\
\hline $\mathrm{S} 13$ & & 3.0 & & & & & 1.71 & 50.9 & 66.9 \\
\hline
\end{tabular}

${ }^{*} \mathrm{BSA}=$ Bottom Slice Area; PA = Projection Area; MDC = Modified Drape Coefficient.

\section{Bottom slice area and projection area}

Table 2 shows the analysis of drape area for both bottom slice and boundary curve (projection) of the entire sample. The samples were divided into three classes (soft, moderate rigid and rigid) on the basis of stiffness (strip method). Ranges of the bottom-slice area (BSA) were observed in distinct limits among the different fabric classes. Soft fabrics ranged $5.29 \mathrm{~m}^{2}$, where semi-rigid and rigid fabrics ranged $14.57 \mathrm{~cm}^{2}$ and $52.84 \mathrm{~cm}^{2}$ respectively. On the other hand, projection area (PA) overlapped among the different classes of fabric stiffness. Projection area ranged from $135.31 \mathrm{~cm}^{2}$ to $205.32 \mathrm{~cm}^{2}\left(70.01 \mathrm{~cm}^{2}\right)$ and $191.05 \mathrm{~cm}^{2}$ to $233.75 \mathrm{~cm}^{2}\left(42.7 \mathrm{~cm}^{2}\right)$ for semirigid and rigid classes respectively. Projection area compared to the BSA has wider range in soft and moderate rigid fabrics; where, BSA has shown narrow range in different fabric classes.

Variation in mean BSA values compared to PA also revealed narrow range for all fabric classes. On the other hand, averages for both drape areas i.e. BSA and PA have shown distinct values for each fabric class. Modified drape coefficient (MDC) based on BSA was computed according to Eq. 2 along with DC as shown in table 2. Both of these drape indicators (MDC and DC) have shown different trends, as their corresponding areas, shown in figure 5 .

$$
\text { Modified drape coefficient }(M D C)=\frac{B S A}{S A} \times 100
$$

where

$B S A$ is bottom slice area;

$S A$ - original sample area.

Overall comparison of BSA and PA is shown in figure 5. The trend between BSA \& PA from softer (Sample No. 1-2) to rigid fabrics (Sample No. 10-13) is shown in the figure with increasing area. Importantly, the change in trend for both drape areas (BSA and PA)

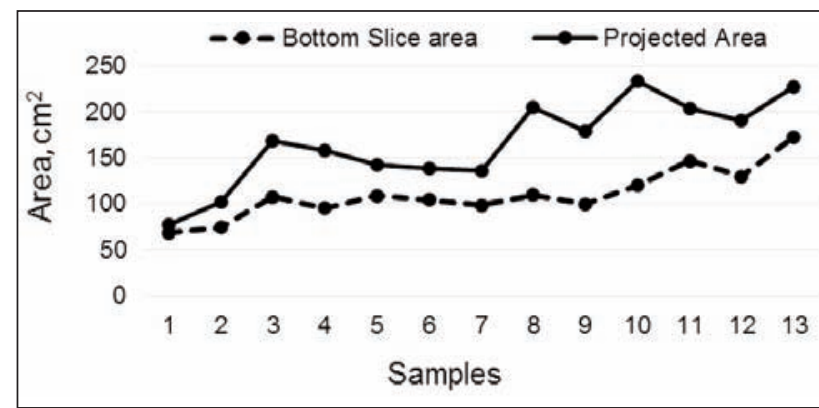

Fig. 5. Overall comparison of Bottom-slice and Projection area

was non-conforming with each other. Though most of the observations have shown same trend, however, some samples (No. 5 and 11) moved in the reverse directions. Additionally, BSA graph line in figure 5, divided itself into three distinct regions whereas, PA due to higher fluctuations could never. Contrary to BSA, PA in rigid class is superseded by semi-rigid class: as the PA value of sample no. $8\left(205.32 \mathrm{~cm}^{2}\right)$ in moderate rigid class was higher than sample no. $11\left(202.90 \mathrm{~cm}^{2}\right)$ and $12\left(191.05 \mathrm{~cm}^{2}\right)$ in rigid class. It means, DC misclassifies fabrics based on PA. These results are supported by the findings of [24, 25], they have shown different DCs for different materials. This was due to the support variations that occur in fabric adjacent-sides below the highest point of the boundary. lin the case of BSA, support is consistent with fabric adjacent sides and consequently, fewer fluctuations were detected; this proves that BSA is a better reference for the actual realization of fabric drape.

\section{Three dimensional drape evaluation}

Three-dimensional space provides more options and information to evaluate fabric drape. Therefore, MDC based on BSA is evaluated and compared with conventional drape indicator DC against the bending 


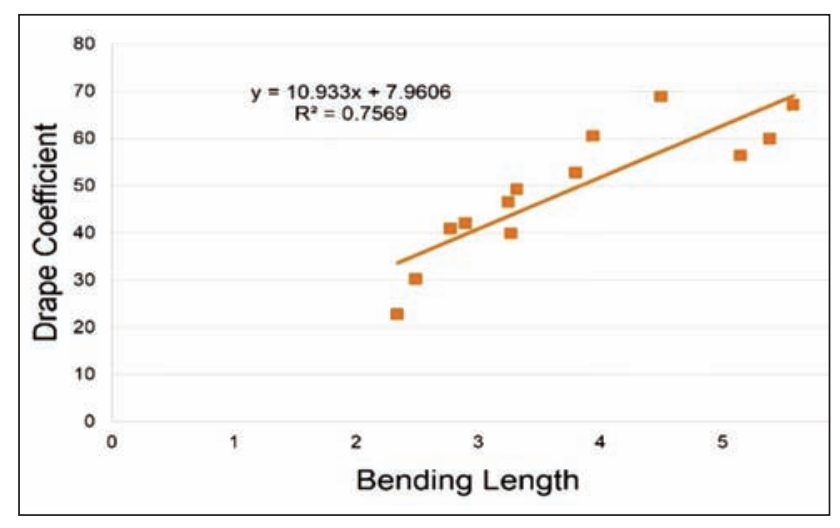

a

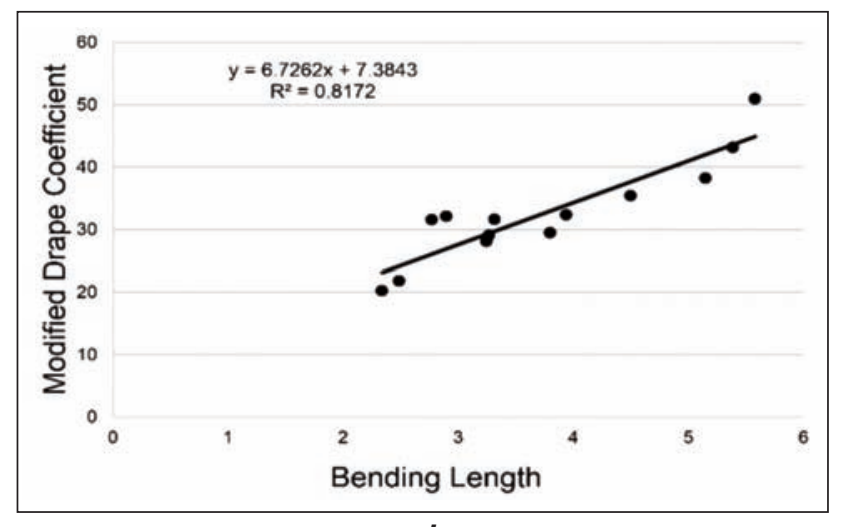

$\boldsymbol{b}$

Fig. 6. Comparison of $a$ - Drape Coefficient and $b$-Modified Drape Coefficient against bending length measured by the strip method

stiffness. Comparison of DC and MDC against the bending stiffness (strip method) is shown in figure 6 . Figure $6, b$ indicates that MDC conforms more to the data compared to DC with R-square values 0.81 . Figure 6 , a with R-square value 0.75 shows more variations for the conventional DC compared to MDC. These results are according to the findings of [26] who stated the effect of stiffness on fabric drape.

This proves that the fabric drape conforms more to bottom slice area (at the highest point of the actual boundary curve) than the projection area. Results of MDC demonstrate the optimization in fabric drape measurement compared to the previously proposed DC. Thus, MDC is a more reliable drape indicator.

\section{CONCLUSIONS}

In this research, 3D drape model has been evaluated with slice function and modification in traditional drape coefficient is proposed successfully. Optimization in the proposed DC is based on bottom slice-area, instead of the projection area. Modified Drape Coefficient increases with the increase of fabric stiffness. The results proved that bending stiffness conforms more to the MDC compared to the DC (previously proposed).

These results will be more advantageous in creating computer simulations and fabric drapability prediction. Though, the fabric samples are small, the results are reasonably acceptable. However, in future, the effect of different textile materials and their manufacturing parameters on the modified drape coefficient is needed to be evaluated before a generalized conclusion can be made.

\section{ACKNOWLEDGEMENT}

This work is supported by National Natural Science Foundation of China (Grant No.61572124).

\section{BIBLIOGRAPHY}

[1] Hu, J., Chan, Y-F., Effect of fabric mechanical properties on drape, In: Textile Research Journal, 1998, 68, 1, pp. 57-64

[2] Frydrych, I., Dziworska, G., Cieślińska, A., Mechanical fabric properties influencing the drape and handle, In: International Journal of Clothing Science and Technology, 2000, 12, 3, pp. 171-183

[3] Robson, D., Long, C. C., Drape analysis using imaging techniques, In: Clothing and Textiles Research Journal, 2000, 18, 1, pp. 1-8

[4] Carrera-Gallissà, E., Capdevila, X., Valldeperas, J., Evaluating drape shape in woven fabrics, In: The Journal of The Textile Institute, 2016, 103, 3, pp. 325-36

[5] Magnenat-Thalmann, N., Volino, P., From early draping to haute couture models: 20 years of research, In: The Visual Computer, 2005, 21, 8-10, pp. 506-519

[6] Chu, C. C., Cummings, C. L., Teixeira, N. A., Mechanics of elastic performance of textile materials Part V: A study of the factors affecting the drape of fabrics - The development of a drape meter, In: Textile Research Journal, 1950, 20, 8, pp. 539-548

[7] Cusick, G., The measurement of fabric drape, In: Journal of the Textile Institute, 1968, vol. 59, no. 6, pp. 253-260

[8] Collier, B. J., Measurement of fabric drape and its relation to fabric mechanical properties and subjective evaluation, In: Clothing and Textiles Research Journal, 1991, 10, 1, pp. 46-52

[9] Behera, B., Pangadiya, A., Drape measurement by digital image processing, In: Textile Asia, 2003, 34, 11, pp. $45-50$

[10] Vangheluwe, L., Kiekens, P., Time dependence of the drape coefficient of fabrics, In: International Journal of Clothing Science and Technology, 1993, 5, 5, pp. 5-8 
[11] Agrawal, S., Study of height dependency of drape parameters, In: International Journal of Engineering Research and Application, 2013, 3, 5

[12] Li, Q. F., Yuan, Y., Relevance analysis between drapability and mechanical properties of the silk fabric, In: International Conference on Control Engineering and Mechanical Design (CEMD 2017): ASME Press, 2018

[13] Jeong, Y., A study of fabric-drape behaviour with image analysis part I: Measurement, characterisation, and instability, In: Journal of the Textile Institute, 1998, 89, 1, pp. 59-69

[14] Carrera Gallissà, E., Juan, C., Javier, F., Valldeperas Morell, J., Abril, H. C., New approach to assessing fabric drape based on the fractal dimension, In: Fibres and textiles in eastern Europe, 2015, 23, 5 (113), pp. 66-70

[15] Payvandy, P., Evaluation of fabric drape coefficient using image processing and fractal dimension, In: The 7th Iranian Conference on Machine Vision and Image Processing, Iran University of Science and Technology, Iran 2011

[16] Park, C. K., Kim, S., Yu, W. R., Quantitative fabric drape evaluation system using image processing technology (Part 1: Measurement system and geometric model), In: Journal of testing and evaluation, 2004, 32, 2, pp. 131-137

[17] Magnenat-Thalmann, N., Volino, P., Bonanni, U., Summers, I. R., Bergamasco, M., Salsedo, F., Wolter, F. E., From physics-based simulation to the touching of textiles: The HAPTEX Project, In: IJVR, 2007, 6, 3, pp. 35-44

[18] Farajikhah, S., Madanipour, K., Saharkhiz, S., Latifi, M., Shadow Moiré aided 3-D reconstruction of fabric drape, In: Fibers and Polymers, 2012, 13, 7, pp. 928-935

[19] Glombikova, V., Kus, Z., Drape evaluation by the $3 D$ drape scanner, In: Journal of Textile \& Apparel/Tekstil ve Konfeksiyon, 2014, 24, 3, pp. 279-285

[20] Jevšnik, S., Geršak, J., Modelling the fused panel for a numerical simulation of drape, In: Fibres \& Textiles in Eastern Europe, 2004, 12, 1, pp. 47-52

[21] Wu, G., Yu, Z., Hussain, A., Zhong, Y., 3D drape reconstruction and parameterization based on smartphone video and Elliptical Fourier Analysis, In: Procedia Computer Science, 2017, 108, pp. 1552-1561

[22] Wu, G., Li, D., Hu, P., Zhong, Y., Pan, N., Automatic foot scanning and measurement based on multiple RGB-depth cameras, In: Textile Research Journal, 2018, 88, 2, pp. 167-181

[23] ASTM D 1388-08, Standard Test Method for Stiffness of Fabrics, 2008

[24] Mizutani, C., Amano, T., Sakaguchi, Y., A new apparatus for the study of fabric drape, In: Textile Research Journal, 2005, 75, pp. 81-87

[25] Cusick, G., The dependence of fabric drape on bending and shear stiffness, In: Journal of the Textile Institute Transactions, 1965, 56, 11, pp. T596-T606

[26] Gulsum, G. P., Musa, K., A new image analysis based device and a new method to determine fabric drape and bending stiffness, In: Industria Textilă, 2015, 66, 3, pp. 146-152

\section{Authors:}

AZMAT HUSSAIN ${ }^{1,3}$, TAYYAB NAVEED ${ }^{1,5}$, DANISH IQBAL ${ }^{4}$, ZHICAI YU ${ }^{1}$, WANG XIN ${ }^{1}$, IQBAL WAQAR 6 , YUEQI ZHONG ${ }^{1,2}$

${ }^{1}$ College of Textiles, Donghua University, Songjiang District, 201620 Shanghai, China

${ }^{2}$ Key Laboratory of Textile Science \& Technology of Ministry of Education, College of Textiles, Donghua University, Songjiang District, 201620 Shanghai, China

${ }^{3}$ Bahauddine Zakariya University, College of Textile Engineering, 54000 Multan, Pakistan

${ }^{4}$ Central Cotton Research Institute, section: Fiber Technology, Multan, Pakistan

${ }^{5}$ Department of Textile Engineering and Technology, University of the Punjab, Lahore

${ }^{6}$ School of Textile, Tianjin Polytechnic University, Tianjin, China

e-mail: azmathussain@bzu.edu.pk; 2195987544@qq.com; idanish424@gmail.com; 1039598561@qq.com; wangxin19930411@163.com; ravianwaqar@hotmail.com

Corresponding authors:

YUEQI ZHONG

e-mail: zhyq@dhu.edu.cn 